\section{Studia}

\section{z Filologii Polskiej i Słowiańskiej}

DOI: $10.11649 /$ sfps.2147
Studia z Filologii Polskiej i Słowiańskiej, 56

Warszawa 2021

Article No. 2147

Citation:

Mikołajczak-Matyja, N. (2021). Skojarzenia werbalne w Narodowym Korpusie Języka Polskiego: Przyczynek do badań nad werbalnym stereotypem inwalidy. Studia z Filologii Polskiej i Słowiańskiej, 56, Article 2147. https://doi.org/10.11649/sfps.2147

Nawoja Mikołajczak-Matyja (Uniwersytet im. Adama Mickiewicza w Poznaniu)

\title{
Skojarzenia werbalne w Narodowym Korpusie Języka Polskiego: przyczynek do badań nad werbalnym stereotypem inwalidy
}

\section{Wstęp}

Od kilkudziesięciu lat dużą rolę w badaniach prowadzonych w ramach nauk humanistycznych pełnią korpusy językowe: zbiory uporządkowanych danych języka mówionego i pisanego, magazynowane i udostępniane w formie elektronicznej, zadaniem których jest odzwierciedlenie określonego języka (Lewandowska-Tomaszczyk, 2005a; Waliński, 2005). Zwraca się uwagę, iż korpus nie jest „lustrzanym odbiciem” tekstowej rzeczywistości języka (Chlebda, 2013, s. 9) i że zarówno samo przeprowadzanie badań korpusowych, jak i opracowywanie uzyskanych danych jest i musi być uzupełniane wiedzą językową i intuicją zarówno badacza, jak i, często, tzw. naiwnych użytkowników języka. Uznaje się zatem konieczność „dywersyfikacji źródeł oraz stosowania zasady komplementarności”, w tym uzupełniania analiz przez dane introspekcyjne (Kiklewicz, 2018, s. 94).

This is an Open Access article distributed under the terms of the Creative Commons Attribution 3.0 PL License (creativecommons.org/licenses/by/3.0/pl/), which permits redistribution, commercial and non-commercial, provided that the article is properly cited. (c) The Author(s) 2021.

Publisher: Institute of Slavic Studies, Polish Academy of Sciences

[Wydawca: Instytut Slawistyki Polskiej Akademii Nauk] 
W ostatnich dziesięcioleciach nasiliło się wykorzystywanie korpusów do badań z pogranicza językoznawstwa i nauk społecznych. Wiele z tych badań kwalifikuje się jako analizy socjolingwistyczne. W przeglądowych pracach Bakera na temat stosowania badań korpusowych w socjolingwistyce (Baker, 2006, 2010) kładzie się nacisk na rolę analiz kolokacji i konkordancji. Pozwalają one m.in. na określenie tzw. preferencji semantycznej i prozodii semantycznej. Określanie preferencji semantycznej badanej jednostki leksykalnej polega na sprawdzaniu, z wyrazami o jakim (wspólnym) znaczeniu jednostka ta często łączy się w tekstach korpusu, czyli inaczej na odkrywaniu tendencji współwystępowania jednostki z elementami określonej kategorii semantycznej (Baker, 2006, 2010; Stubbs, 2001). Natomiast prozodia semantyczna wyznacza nacechowanie (pozytywne lub negatywne) badanej jednostki, określone przez znaczenie współwystępujących z nią innych wyrazów, czyli wyraźniej (niż sama preferencja) wskazuje postawy autorów analizowanych wypowiedzi (Baker, 2006, 2010; Lewandowska-Tomaszczyk, 2005b). I tak np. Baker odtworzył w wyniku analizy kolokacji i konkordancji wyrazu spinster ('stara panna') dwie negatywne prozodie: jedną związaną z brakiem zaspokojenia potrzeb seksualnych (np. wyrazy: sfrustrowana, głodna miłości i seksu, samotna), drugą - z brakiem atrakcyjności (np. wyrazy: okropna, zwyczajna, wysuszona, przesadnie wymalowana itp.) (Baker, 2006). Natomiast Mautner, analizując kolokaty słowa elderly ('stary'/'starszy'/'senior'), wykrył prozodię związaną ze słabym zdrowiem i niepełnosprawnością (wskazaną np. przez wyrazy słaby, chory, ofiara, pomoc itd.) (Mautner, 2007).

Przedstawione wyżej przykłady ukazują możliwość traktowania analiz korpusowych jako istotnego narzędzia badania stereotypów, rozumianych jako nadmiernie uogólnione i uproszczone obrazy o wyraźnie zaznaczonym aspekcie oceniająco-afektywnym, dotyczące jakiegoś elementu rzeczywistości, na przykład grupy ludzi wyodrębnionej według kryterium typu płeć, wiek, narodowość, dysfunkcja itp. W bogatej literaturze na temat stereotypów podkreśla się od dawna, że są one nabywane, utrwalane i rozpowszechniane przy znaczącym udziale języka i komunikacji, że język ułatwia kategoryzację rzeczywistości, a także jest środkiem i narzędziem utrwalania i przekazywania tej kategoryzacji (por. np. Chlewiński, 1992; Greń, 2001; Stangor \& Schaller, 1999). Rozpowszechnianie stereotypów w ustnych i pisemnych aktach komunikacji nie musi być intencjonalne - może być efektem określonych cech uzusu językowego, np. częstego używania określonych form czy typowych kontekstów użycia (np. Maass \& Arcuri, 1999; Mills, 2008). Poglądy takie stały 
się podstawą stosowania, od pierwszej połowy XX wieku, licznych werbalnych metod rekonstruowania stereotypów. Większość z nich polega na pozyskiwaniu określonych reakcji werbalnych, ustnych lub pisemnych, od użytkowników danej społeczności językowej w przygotowanej sytuacji badawczej ${ }^{1}$

W dobie powstających coraz liczniej korpusów nasuwa się pytanie o sens kontynuowania badań nad stereotypami z użyciem takich klasycznych metod, skoro istnieje możliwość badań opartych na analizie zasobów korpusowych, stanowiących źródło bardzo bogatych i (wyjściowo) obiektywnych danych. Z pytaniem tym łączy się przekonanie o konieczności oszacowania przydatności informacji otrzymywanych przy zastosowaniu metod klasycznych do uzupełniania danych pozyskanych z korpusu. Próbę takiego oszacowania stanowią analizy zawarte w następnych częściach niniejszego artykułu.

W nielicznych prowadzonych w XXI wieku badaniach porównawczych uzyskiwano zróżnicowaną zbieżność rezultatów testu skojarzeniowego z danymi korpusowymi. Na przykład Schulte im Walde i in. (Schulte im Walde i in., 2008) porównywali skojarzenia uzyskane od użytkowników języka niemieckiego z korpusem 20 milionów wyrazów z czasopism i stwierdzili, że ponad 3/4 reakcji na hasła czasownikowe i ponad $80 \%$ na rzeczownikowe współwystępowało z hasłem przynajmniej jeden raz w materiałach korpusu, w odległości $\leq 20$ wyrazów. Mollin porównywała skojarzenia z Edinburgh Associative Thesaurus dla 30 wybranych losowo haseł ze zbiorem kolokatów dla tych haseł znalezionych w British National Corpus w odległości $\leq 4$ wyrazów (Mollin, 2009). Ponad $50 \%$ par hasło-skojarzenie znalazło się w zbiorze hasło-kolokat z korpusu ${ }^{2}$.

\section{Podstawa badania: wybór hasła, korpusu i testu}

Hasło: Do analizy wybrano słowo inwalida. Prawie do końca XX wieku istotą „inwalidztwa” w rozumieniu ustawowym była niezdolność do wykonywania pracy, stanowiąca następstwo długotrwałej albo stałej wady czy defektu fizycznego lub umysłowego (Więckowska, 2004) i w taki właśnie sposób - poprzez niezdolność do

1 Przeglądy i przykłady różnych badań i metod w polskiej literaturze na temat stereotypów można znaleźć np. w pracach: Bartmiński \& Panasiuk, 2010; Karwatowska \& Szpyra-Kozłowska, 2005.

${ }^{2}$ W obliczeniach brano pod uwagę jedynie kolokaty, które współwystępowały $\mathrm{z}$ hasłem w korpusie więcej niż 5 razy (Mollin, 2009). 
pracy - najczęściej definiowano i nadal często się definiuje wyraz inwalida w słownikach (por. np. SWO, 1980; SJPDun, 1996; internetowy Słownik PWN - PWN, b.d. - lub definicja na stronie https://slownik.rownosc.info/ pod hasłem „niepełnosprawność”: Peretiatkowicz-Czyż \& Todys, 2015). Współcześnie pojawiają się także definicje, które nie nawiązują bezpośrednio do wykonywania pracy, natomiast sugerują synonimię między słowami inwalida a niepetnosprawny. Ten drugi termin jest zdecydowanie częściej stosowany we współczesnej literaturze psycho-i socjologicznej i traktowany jako bardziej poprawny w dyskursie integracji, bo mniej obciążony negatywnymi konotacjami. Właśnie m.in. wyrazistość afektywno-emocjonalna terminu inwalida stała się podstawą jego wyboru do badania, zwiększa ona bowiem prawdopodobieństwo kształtowania się takiego obrazu, który będzie miał cechy stereotypu. W myślenie o osobach niepełnosprawnych, inwalidach itp. włącza się często element lęku i niepewności, lęku związanego $\mathrm{z}$ własnym funkcjonowaniem osoby pełnosprawnej, z uświadomieniem sobie nietrwałości zdrowia i płynącego stąd niebezpieczeństwa utraty samodzielności, a nawet realności śmierci (Barnes \& Mercer, 2008; Biernat \& Dovidio, 2008; Ostrowska, 2002). Cechy te mogą się wyraźnie ujawniać we wszystkich klasycznych technikach badania stereotypów, stąd ich porównanie $\mathrm{z}$ danymi korpusowymi wydaje się bardzo interesujące.

Korpus: Analizy przeprowadzono, korzystając z Narodowego Korpusu Języka Polskiego (NKJP, b.d.), uruchomionego w 2012 roku, a dokładniej z tzw. zrównoważonego podkorpusu NKJP, liczącego 300 milionów segmentów (czyli około 250 milionów słów ${ }^{3}$ ). Przy opracowywaniu NKJP przyjęto, iż w podkorpusie zrównoważonym żaden z typów tekstów nie obejmuje więcej niż połowę zasobów, stąd najsilniej reprezentowane teksty prasowe stanowią 50\% podkorpusu (Górski \& Łaziński, 2012).

Test: Do analiz wybrano test skojarzeń swobodnych, czyli technikę badawczą, która polega na prezentacji słowa-hasła wraz z instrukcją zalecającą badanym podanie dowolnego innego wyrazu lub wyrazów w odpowiedzi na usłyszane lub przeczytane hasło. Jest to metoda o ponad stuletniej już tradycji i szerokim zasięgu stosowania ${ }^{4}$.

${ }^{3}$ Jako segmenty w NKJP traktowano ciągi znaków nie dłuższe niż słowa (rozumiane jako maksymalne ciągi znaków nie będących separatorami słów), a w niektórych, ściśle określonych przypadkach ciągi krótsze niż słowa (dokładna charakterystyka sposobu wyodrębniania i liczenia segmentów por. Szałkiewicz \& Przepiórkowski, 2012).

${ }^{4}$ Przegląd informacji na temat mechanizmu skojarzeniowego, typów testu i ich zastosowań dawniejszych i współczesnych można znaleźć m.in. w pracach: Deese, 1965; Kurcz, 1976; Mikołajczak-Matyja, 2012. 
Zaletą stosowania tego testu do badań nad stereotypami jest możliwość uzyskania szerokiego spektrum danych - nie tylko o charakterze afektywno-ewaluacyjnym, ale także innych, w różnorodny sposób powiązanych $z$ denotatem hasła. Poszukiwanie takich danych w potencjalnie bardzo szerokim zakresie kontekstów zawartych w korpusie wydaje się tym bardziej interesujące. Można założyć, że skojarzenia silne, a jednocześnie często współwystępujące z hasłem w materiale korpusowym stanowią źródło informacji szczególnie istotnych dla badanego stereotypu, a nawet że są one kluczowymi, definicyjnymi elementami znaczenia badanego wyrazu.

Pochodzenie materiału skojarzeniowego: Do analiz, ze względu na datowanie źródeł zawartych w NKJP (przed 2012 rokiem), zdecydowano się wykorzystać dane skojarzeniowe pozyskane w badaniach własnych z 2011 roku. 40 uczniów i uczennic polskich liceów ogólnokształcących, w wieku 15-18 lat, otrzymało następującą instrukcję: „Wypisz dowolną liczbę słów, które przychodzą Ci na myśl w związku z poniższym hasłem. Masz na to 2 minuty. Nie zastanawiaj się nad odpowiedzią i wyborem wyrazów". Uzyskano w sumie 323 reakcje. Połączenie reakcji identycznych podanych przez różnych badanych stanowiło podstawę wyznaczenia wskaźnika liczby różnych reakcji; wyniósł on 192. Postanowiono poszukiwać w materiałach korpusowych jedynie skojarzeń istotniejszych, czyli powtarzalnych, nieindywidualnych, tj. podanych przez min. 2 osoby. Stanowią one zbiór 33 reakcji, przedstawionych (wraz z częstością ich podawania przez badanych) w tabeli 1 (zob. s. 8).

\section{Analiza: poszukiwanie danych skojarzeniowych w korpusie}

Punktem wyjścia analiz przedstawianych w tej pracy były dane skojarzeniowe: sprawdzenie, czy i jak często wyraz inwalida współwystępuje z nimi w zasobach korpusowych ${ }^{5}$. Sprawdzono współwystępowanie słowa inwalida kolejno z każdym z 33 skojarzeń, z użyciem narzędzia szukającego kontekstów (konkordancji) zawierających oba wyrazy - inwalida i skojarzenie - w zadanym odstępie. Do badania konkordancji w NKJP wykorzystano wyszukiwarkę PELCRA. W okienku wyszukiwarki wprowa-

${ }^{5}$ Przeprowadzono także badanie, w którym punktem wyjścia były dane z NKJP uzyskane przez zastosowanie narzędzia Kolokator, porównane następnie bardzo szczegółowo z wynikami testu skojarzeniowego. Stanowi ono przedmiot odrębnej pracy (Mikołajczak-Matyja, 2020), por. także „Podsumowanie i wnioski” w niniejszym artykule. 
dzano zapisy ,inwalida ${ }^{* \star} \_X^{\star * ”}(X-$ podstawowa forma gramatyczna skojarzenia), w których znak „**" powoduje wyszukiwanie wszystkich wariantów fleksyjnych danego wyrazu, a znak „__” (potrójny podkreślnik) - wyszukiwanie współwystępowania wyrazu po jednej jego stronie z wyrazami po drugiej (według instrukcji w: Pęzik, 2012). Zdecydowano się przeprowadzić porównanie dla 2 wariantów odstępu: 0 i 5, czyli dla występowania wyrazu inwalida i skojarzenia w bezpośrednim sąsiedztwie i w odstępie maksimum 5 wyrazów. Można zatem zakładać, że w znalezionych kontekstach badana para wyrazów najczęściej będzie należeć do tego samego zdania prostego, do składowych zdań tego samego zdania złożonego lub do zdań sąsiadujących ze sobą. Wprowadzenie do analiz większego odstępu $(\leq 5)$ wydaje się wskazane ze względu na rzeczownikowy charakter uzyskanego zbioru skojarzeń ${ }^{6}$, potencjalnie utrudniający współwystępowanie niektórych asocjacji z rzeczownikiem inwalida w bezpośrednim sąsiedztwie. W formułowaniu zadania dla wyszukiwarki nie wskazano konieczności zachowania szyku „najpierw inwalida, potem $X$ ”. Jak wspomniano wyżej, zadawano wyszukiwanie w podkorpusie zrównoważonym. Jednakże w kilku przypadkach (por. niżej) uzupełniono badanie, zadając wyszukiwanie w całym korpusie.

Do analiz wykorzystano wszystkie konkordancje znalezione przez narzędzie, z wyjątkiem tych, w których wyraz inwalida stanowi część nazwy geograficznej (np. Plac Inwalidów), oraz tych, których kontekst wskazuje na znaczenie wyrazu-asocjacji prawdopodobnie niewykorzystane przez badanego podającego taką reakcję. To drugie ograniczenie wymaga wyjaśnienia. Interpretacja wyników badania skojarzeniowego, czyli odtwarzanie prawdopodobnej ścieżki skojarzeniowej między bodźcem a reakcją, opiera się na specyfice języka stanowiącego przedmiot badania oraz na wiedzy i intuicji badacza (wspartej źródłami na temat języka). Zakładamy np., że reakcja kula na hasło inwalida dotyczy najprawdopodobniej kuli w znaczeniu „podpórki dla osoby niepełnosprawnej” (por. np. definicja w ISJP, 2014, t. 1, s. 729), zatem znaleziony w korpusie kontekst typu został inwalida za sprawa policyjnej kuli można wyłączyć z analiz. Założenie takie, mimo iż nie musi być zawsze stuprocentowo słuszne (bo nie znamy osobistych doświadczeń i całości wiedzy danego respondenta), wydaje się jednak sensownie ograniczać analizę uzyskanego materiału. Na podobnej zasadzie wyłączono z obliczeń konteksty, w których skojarzenie wózek odnosi się

${ }^{6}$ Wyjątkiem są skojarzenia, które mogą w odpowiednich kontekstach stanowić rzeczownik lub przymiotnik albo imiesłów: niepetnosprawny, chory, niewidomy, poszkodowany. Zgodność kategorii gramatycznej między bodźcem a reakcją cechuje zazwyczaj znaczącą większość odpowiedzi uzyskiwanych w badaniach skojarzeniowych; jest to cecha odzwierciedlająca budowę słownika umysłowego (por. np. Łobacz \& Mikołajczak-Matyja, 2002; Mollin, 2009). 
do wózka dziecięcego (np. krawężniki to kłopot dla matek z wózkami, rowerzystów i inwalidów). Z obliczeń wykluczono także przypadki użycia wyrazów w znaczeniach metaforycznych i/lub stanowiących część utartych powiedzeń czy frazeologizmów (np. noga: rzucanie kłód pod nogi spółdzielniom inwalidów). Pozostałe konteksty użycia wyrazów-asocjacji uwzględniano w obliczeniach, zakładając ich możliwą zbieżność ze ścieżką skojarzeniową, która spowodowała pojawienie się danej reakcji podczas badania. Na przykład wystąpienie reakcji rodzina może wynikać z aktywizowania bardzo różnych doświadczeń i opinii: że inwalida często nie ma rodziny, że jego rodzina ma kłopoty większe niż inna itd. U podstaw reakcji problem mogą występować opinie, że inwalida ma problem bądź że jest przyczyną określonych problemów, a u podstaw reakcji niepelnosprawny - opinia zarówno, że inwalida to inna nazwa niepełnosprawnego, jak i że jest to określenie podtypu osoby niepełnosprawnej.

W przypadku dwóch skojarzeń (w tabeli oznaczonych gwiazdką) forma wpisana w wyszukiwarkę była odmienna niż ta podana przez badanych: wpisanie w okienko formy udogodnieniela oraz pokrzywdzony nie uruchamia wyszukiwania (powoduje brak odpowiedzi ${ }^{7}$ ), dlatego zastąpiono je bezokolicznikami udogodnić i pokrzywdzić; znalezione konteksty są zgodne z formą skojarzenia, czyli, odpowiednio, rzeczownika odsłownego i imiesłowu.

Liczby uzyskanych kontekstów dla odstępu $0 \mathrm{i} \leq 5$ przedstawiono w tabeli 1 (odpowiednio: $\mathrm{O} 0 \mathrm{i} \mathrm{O} 5)^{8}$. L - liczba osób $(\mathrm{N}=40)$ podających dane skojarzenie. Reakcje w tabeli uporządkowane są wg ich siły skojarzeniowej (od 28 do 2).

\section{Wyniki dla odstępu 0}

Dla reakcji o najsilniejszym współwystępowaniu w materiałach NKJP wartości testu chi kwadrat, wskazujące stopień istotności współwystąpień ${ }^{9}$ wynoszą odpowiednio (w nawiasach liczba współwystąpień, dalej wartość testu): niepetnosprawny (12) 1,440.34, chory (11) 419.86, poszkodo-

7 W przeciwieństwie do odpowiedzi „znaleziono 0 akapitów pasujących do zapytania”, która stanowiłaby efekt uruchomienia wyszukiwania.

8 Są to liczby przykładów dostarczanych przez wyszukiwarkę (zmniejszone o te odrzucane po analizie według podanych wyżej zasad), a nie podawane przez nią liczby akapitów.

9 Test wskazuje, w jakim stopniu liczba współwystąpień dwóch wyrazów wynika z ogólnej częstości występowania tych wyrazów w korpusie oddzielnie: im wyższa wartość testu, tym niższe prawdopodobieństwo, że liczba współwystąpień wynika tylko i wyłącznie z częstości występowania wyrazów oddzielnie (Pęzik, 2012). 
Nawoja Mikołajczak-Matyja Skojarzenia werbalne w Narodowym Korpusie Języka Polskiego...

wany (9) 1,871.33, kaleka (7) 7,384.53, rehabilitacja (7) 928.23, wózek (6) 770.75, pomoc (6) 26.84 , problem (5) $10.45^{10}$. Najwyższą siłę połączenia z wyrazem inwalida w tekstach NKJP mają zatem skojarzenia: niepełnosprawny (w liczbach bezwzględnych) i kaleka (według wartości testu chi kwadrat). Drugie pod względem częstości bezwzględnej skojarzenie chory ma stosunkowo niską wartość testu chi kwadrat.

Tabela 1. Liczba skojarzeń i liczba ich współwystąpień z wyrazem inwalida w odstępie 0 i $\leq 5$

\begin{tabular}{|c|c|c|c|c|c|c|c|}
\hline \multicolumn{2}{|c|}{ Reakcje skojarzeniowe } & \multicolumn{2}{|c|}{$\begin{array}{l}\text { Wystąpienia } \\
\text { korpusowe }\end{array}$} & \multicolumn{2}{|c|}{ Reakcje skojarzeniowe } & \multicolumn{2}{|c|}{$\begin{array}{l}\text { Wystąpienia } \\
\text { korpusowe }\end{array}$} \\
\hline Reakcja & $\mathrm{L}$ & $\mathrm{O} 0$ & O 5 & Reakcja & $\mathrm{L}$ & O 0 & O 5 \\
\hline wózek (inwalidzki) & 28 & 6 & 82 & proteza/y & 3 & $\mathbf{0}$ & 8 \\
\hline niepełnosprawny & 16 & 12 & 90 & człowiek/ludzie & 2 & 3 & 67 \\
\hline kula/e & 12 & 1 & 13 & złamanie/a & 2 & $\mathbf{0}$ & $\mathbf{0}$ \\
\hline choroba & 8 & $\mathbf{0}$ & 13 & niedołężność & 2 & $\mathbf{0}$ & $\mathbf{0}$ \\
\hline wypadek & 8 & 2 & 36 & niewidomy & 2 & 3 & 18 \\
\hline szpital & 7 & 1 & 12 & noga/i & 2 & 1 & 30 \\
\hline niepełnosprawność & 7 & $\mathbf{0}$ & 10 & cierpienie & 2 & $\mathbf{0}$ & 1 \\
\hline pomoc & 7 & 6 & 43 & miłość & 2 & $\mathbf{0}$ & 1 \\
\hline kaleka & 6 & 7 & 13 & szacunek & 2 & $\mathbf{0}$ & $\mathbf{0}$ \\
\hline kalectwo & 5 & $\mathbf{0}$ & 4 & poszkodowany & 2 & 9 & 33 \\
\hline chory & 5 & 11 & 63 & rodzina & 2 & 2 & 126 \\
\hline trudność/ci & 5 & 1 & 2 & udogodnienia $^{*}$ & 2 & 1 & 6 \\
\hline tolerancja & 4 & $\mathbf{0}$ & $\mathbf{0}$ & akceptacja & 2 & $\mathbf{0}$ & 1 \\
\hline rehabilitacja & 4 & 7 & 43 & pokrzywdzony ${ }^{\star}$ & 2 & $\mathbf{0}$ & 1 \\
\hline problem/y & 4 & 5 & 26 & nieostrożność & 2 & $\mathbf{0}$ & $\mathbf{0}$ \\
\hline smutek & 3 & $\mathbf{0}$ & $\mathbf{0}$ & ograniczenia & 2 & 1 & 10 \\
\hline winda & 3 & $\mathbf{0}$ & 4 & & & & \\
\hline
\end{tabular}

15 spośród 33 skojarzeń w ogóle nie występuje w bezpośrednim sąsiedztwie wyrazu inwalida w kontekstach znalezionych w podkorpusie zrównoważonym NKJP, z czego 11 to skojarzenia o najniższych częstościach (8 o częstości =2, czyli

10 Wartości wyliczone z użyciem narzędzia Kolokator wyszukiwarki PELCRA. Wyniki testu podano $\mathrm{w}$ takiej formie, w jakiej podawane są one przez NKJP: tysiące od jednostek oddziela przecinek, liczby całkowite od ułamków - kropka. 
L2 ${ }^{11}$, a 3 o częstości L3). Natomiast tylko 1 kontekst bezpośredni znaleziono dla kolejnych 6 skojarzeń, w tym dla 3 również o najniższej częstości (czyli L2). Mimo różnic $\mathrm{w}$ rangach poszczególnych elementów między zbiorami skojarzeń i kontekstów widoczne są zatem również pewne zbieżności. Do największych różnic między dwoma uporządkowaniami należy: $\mathrm{z}$ jednej strony stosunkowo wysoka liczba kontekstów (9) i wysoka wartość chi kwadrat (druga co do wielkości w tym zbiorze) dla słowa poszkodowany, reakcji o najniższej częstości skojarzeniowej (L2) oraz bardzo wysoka (najwyższa w zbiorze) wartość testu chi kwadrat dla skojarzenia kaleka o częstości L6 (dopiero szósta co do częstości reakcja w zbiorze skojarzeń), a z drugiej strony - brak kontekstów dla słów choroba, niepełnosprawność i kalectwo, wskazanych w teście skojarzeniowym odpowiednio przez 20\%, 17,5\% i 12,5\% grupy respondentów. Ta druga rozbieżność spowodowana jest rzeczownikowym charakterem tych trzech reakcji (utrudniającym gramatycznie poprawne bezpośrednie połączenia z wyrazem inwalida), o czym świadczą najwyższe liczby (12 i 11) połączeń tego wyrazu z formami rzeczownikowo-przymiotnikowymi niepetnosprawny i chory. Główną właściwością zbioru kontekstów bezpośrednich dla wyrazu inwalida w odniesieniu do zbioru skojarzeń wydaje się brak połączeń ze skojarzeniami o charakterze rzeczowników abstrakcyjnych, oznaczających cechy i uczucia: oprócz trzech już wymienionych są to także nieostrożność i niedołężność, a także cechy oznaczające stosunek do innych: tolerancja, szacunek, akceptacja, oraz nazwy uczuć: smutek, cierpienie, miłość.

\section{Wyniki dla odstępu $\leq 5$}

Liczby zawarte w kolumnie „O 5” wskazują, że ze słowem inwalida najczęściej współwystępują, w odległości maksimum 5 wyrazów, niniejsze elementy zbioru skojarzeń (uszeregowano je tu od najwyższej liczby kontekstów znalezionych przez narzędzie do najniższej, wynoszącej 30): rodzina, niepetnosprawny, wózek, człowiek, chory, rehabilitacja, pomoc, wypadek, poszkodowany, noga. Widoczne jest zatem, iz najczęstsze skojarzenia na hasło inwalida - wózek i niepełnosprawny - to wyrazy prawie najczęściej z całego zbioru występujące w kontekstach (o randze odpowiednio III i II). Można je zatem uznać za istotne elementy znaczenia słowa inwalida.

${ }^{11} \mathrm{~W}$ celu uniknięcia niejednoznaczności z literą L (Liczba osób) będą podawane częstości uzyskane w badaniu skojarzeniowym, a częstości wystąpień w korpusie będą przytaczane bez takiego oznaczenia, a jedynie liczbowo. 
Widoczna jest natomiast wyraźna różnica w danych uzyskanych dla skojarzenia rodzina: najniższa częstość wystąpień wśród skojarzeń (L2), a najwyższa wśród kontekstów (ranga I - aż 126 wystąpień). Na ten liczny zbiór składają się jednak głównie cytaty z obrad Sejmu oraz z „Gazety Ubezpieczeniowej”, dotyczące inwalidów wojennych $i$ wojskowych oraz ich rodzin, a dokładniej ich przywilejów/ uprawnień, a zwłaszcza ustaw/przepisów o ich zaopatrzeniu. Stosunkowo duży zbiór współwystępowań wyrazów inwalida i człowiek (67 - ranga IV - a przy tym najniższa siła skojarzeń L2) jest bardziej urozmaicony, ale daje się w nim wyodrębnić dwie wiodące tendencje: są to teksty kwalifikujące człowieka jako inwalidę (człowiek jest/zostaje inwalida - wyraz inwalida pełni tu zatem funkcję orzecznika) lub wymieniające inwalidów razem $z$ innymi grupami osób specjalnej troski, np. ludzi chorych czy starszych. Podobnie jest w przypadku równie słabego skojarzenia (L2) poszkodowany, także o stosunkowo wysokiej częstości współwystępowań (33 - ranga VIII): znaczącą część zbioru kontekstów stanowią fragmenty z „Gazety Ubezpieczeniowej”, w tym kolokacje typu: poszkodowany inwalida, poszkodowany stat się / zostanie inwalida. Natomiast zbiór kontekstów dla słabego skojarzenia noga (także L2) pochodzi z różnych źródeł, a najbardziej typowe jest tu połączenie inwalida bez nogi/nóg. Wyrazy o rangach V-VII - chory (63 konteksty), rehabilitacja i pomoc (po 43) oraz wypadek (36) - stanowią dość silne skojarzenia (o sile, odpowiednio, L5, L4, L7 i L8, a więc podane przez $10 \%$ do $20 \%$ grupy badanych).

Zbiór 15 skojarzeń, które nie występowały w bezpośrednim sąsiedztwie wyrazu inwalida, przy zadanym odstępie $\leq 5$ zmniejszył się do 6 . Zwiększenie odstępu spowodowało pojawienie się kilkunastu współwystępowań inwalidy z rzeczownikami niepetnosprawność i choroba, kilku z kalectwem, a także z nazwami urządzeń typu proteza i winda. Tylko po 1 kontekście pojawiło się dla wyrazów akceptacja, pokrzywdzony, miłość i cierpienie. Natomiast żadnych kontekstów przy odległości maksimum 5 wyrazów nie znaleziono dla skojarzeń: tolerancja, smutek, złamanie, niedołężność, szacunek, nieostrożność. Wydaje się zatem, że zwiększenie zbioru współwystępowań do odległości maksimum 5 wyrazów potwierdza niewielką możliwość znalezienia nazw cech i uczuć w powiązaniu z inwalidą za sprawą badań korpusowych.

Aby upewnić się co do tego wniosku, rozszerzono wyszukiwanie dotyczące tych 6 wyrazów, dla których nie uzyskano ani jednego wspólnego kontekstu. Po pierwsze zadano wyszukanie współwystępowań dla pokrewnych form przymiotnikowych i czasownikowych, czyli: tolerować, tolerancyjny, smutny, złamać, niedołężny, szanować i nieostrożny (dla odstępu $\leq 5$, w korpusie zrów- 
noważonym). Dla $4 \mathrm{z}$ tych 7 form znaleziono konteksty: szanować (3, z czego 2 zawierają połączenie szanować prawa, np. Tak właśnie szanowane sa prawa inwalidów), złamać (2), smutny (1), niedołężny (1). Po drugie zadano wyszukiwanie 6 skojarzeń w ich pierwotnej formie dla odstępu $\leq 5 \mathrm{w}$ całym korpusie (liczącym ponad 1,5 mld słów). Konteksty uzyskano tylko dla 3 z 6 wyrazów: szacunek $\left(9^{12}\right)$, złamanie (2), tolerancja (1).

\section{Podsumowanie i wnioski}

Próba poszukiwania w korpusie kontekstów zawierających bodziec (inwalida) i (powtarzalną) reakcję skojarzeniową daje efekty pozytywne: większość asocjacji współwystępuje w danych korpusowych z wyrazem inwalida. Znaleziono konteksty $\mathrm{z}$ bezpośrednim sąsiedztwem bodźca i reakcji (odstęp 0) dla większości, bo 18 ze zbioru 33 skojarzeń, a przy zwiększeniu odstępu do maksimum 5 liczba ta zwiększa się do 27 (ponad 80\% zbioru skojarzeń). Ponadto znaczna większość skojarzeń (11 z 15), które nie występują w danych korpusowych w bezpośrednim sąsiedztwie wyrazu inwalida, to reakcje o najniższych częstościach (L2 i L3). Przynależność bodźca i reakcji do tej samej kategorii gramatycznej, ograniczająca możliwość występowania niektórych takich wyrazów w bezpośrednim kontekście, przestaje być przeszkodą przy zwiększeniu odstępu do maksimum 5 wyrazów.

Przy odstępie $\leq 5$ wyraźnie uwypuklają się zbieżności między wynikami testu skojarzeń a efektem przeszukiwania korpusu, polegające na dużej sile - w obu zbiorach danych - kilku wyrazów: przede wszystkim wózek i niepetnosprawny, ale także chory, rehabilitacja, pomoc i wypadek. Siła tych pierwszych dwóch reakcji tak w danych korpusowych, jak i w skojarzeniach wskazuje, że inwalidztwo to ten rodzaj niepełnosprawności, którego prototypem jest człowiek na wózku (czyli inwalida narządu ruchu). Można zatem postulować włączanie tej informacji do leksykograficznych definicji wyrazu inwalida lub przynajmniej wykorzystywanie kontekstów zawierających wyrazy niepełnoprawność i wózek w ilustracji materia-

12 Wyszukiwarka zwraca w tym przypadku w sumie 37 przykładów, z czego jednak 2 dotyczą innego znaczenia wyrazu (szacunek finansowy, w znaczeniu przybliżonego określania wartości), a 26 - to wielokrotnie powielone zestawienie tematów z internetowej grupy dyskusyjnej Usenet -- pl.soc.polityka, w którym znalazły się obok siebie: O równe prawa dla inwalidów w Unii Europejskiej O szacunek dla przeszłości... 
łowej artykułu słownikowego ${ }^{13}$. Cztery pozostałe wymienione reakcje powinny natomiast, jak się wydaje, być uwzględniane we wszelkich bardziej szczegółowych rozważaniach semantycznych na temat jednostki leksykalnej inwalida (i w rozważaniach na temat inwalidztwa prowadzonych w ramach innych dziedzin).

Przy odstępie $\leq 5$ wyraźniej uwypuklają się także tendencje dotyczące różnic między częstością skojarzenia na słowo inwalida a częstością współwystępowania pary inwalida-skojarzenie w korpusie. Z jednej strony zbiór przykładów korpusowych wskazuje dużą siłę współwystępowania wyrazu inwalida z kilkoma słabymi skojarzeniami, takimi jak rodzina (zdecydowanie największy zbiór kontekstów) oraz człowiek/ludzie i noga/nogi. Jest to spowodowane głównie dużą liczbą tekstów zawierających cytaty z różnych przepisów i ustaw prawnych na temat osób, które są / stają się inwalidami (w tym inwalidami bez nóg), i ich rodzin. Z drugiej strony badania korpusowe dają mniejszą możliwość wydobycia skojarzeń o znaczeniu ewaluacyjno-emocjonalnym związanych z pojęciem inwalidy, co wyraża się w braku lub bardzo małej liczbie współwystępowań tego wyrazu ze skojarzeniami-nazwami cech i uczuć, przy zadanym odstępie zarówno 0 , jak i 5 . Rozszerzenie badania wykazało, że jest to względnie niezależne od kategorii gramatycznej nazwy cechy czy uczucia i od wielkości przeszukiwanych zasobów. Negatywna prozodia semantyczna badanego wyrazu ujawniona w skojarzeniach nie znajduje pełnego odzwierciedlenia w danych korpusowych.

W analizach badań skojarzeniowych powszechne jest stosowanie podziału na reakcje paradygmatyczne i syntagmatyczne (por. np. Kurcz, 1976; Łobacz \& Mikołajczak-Matyja, 2002; Mollin, 2009). Reakcja syntagmatyczna jest interpretowana jako dalszy ciąg frazy, której część stanowi bodziec (pies-szczeka), a w przypadku skojarzeń paradygmatycznych hasło i reakcja mogą stanowić ten sam możliwy fragment danej wypowiedzi (pies-kot) ${ }^{14}$ (Mikołajczak-Matyja, 2012, s. 108). Korpus stanowi próbkę wyników produkcji języka, a więc próbkę kombinacji słów. Zatem jednym z wyjaśnień niskiej korelacji między danymi skojarzeniowymi a korpusowymi jest fakt podawania przez badanych wielu reakcji

${ }^{13}$ Konieczne jest tu zastrzeżenie, że konteksty współwystępowania wyrazów inwalida i niepetnosprawny nie zawsze wskazują relację podrzędności między nimi; w niektórych przykładach wyszukanych przez narzędzie wyrazy te traktowane są inaczej, np. synonimicznie. Szczegółowa analiza zbioru kontekstów i próba procentowego określenia rodzajów relacji może być przedmiotem odrębnej pracy, która jednak powinna uwzględniać także zmiany diachroniczne.

${ }^{14} \mathrm{Tj}$. wymiana jednego elementu na drugi nie zakłóca poprawności gramatycznej i sensowności tekstu. 
paradygmatycznych, powiązanych z bodźcem określoną relacją semantyczną (jak synonimia, antonimia, meronimia itp.) (Mollin, 2009). Jednakże paradygmatyczny charakter reakcji nie wyklucza możliwości jej współwystępowania z bodźcem w materiale językowym (zwłaszcza przy odległości $>0$ ). Wszystkie analizowane tu asocjacje werbalne miały charakter rzeczownikowy lub rzeczownikowo-przymiotnikowy (jak chory). Wiele skojarzeń należących do tej samej kategorii gramatycznej co hasło może nie tylko współwystępować z nim $\mathrm{w}$ wypowiedziach, ale także wejść $\mathrm{w}$ silną relację syntagmatyczną $\mathrm{z}$ hasłem, por. inwalida-wózek: inwalida na wózku. Dotyczy to także par połączonych silną relacją semantyczną typu część-całość, np. inwalida-noga: inwalida bez nogi, inwalida-rodzina: rodziny inwalidów itp.

W innych analizach, przedstawionych w pracy Wartość korpusów językowych jako materiatu do badania stereotypów osób z niepelnosprawnością: porównanie wyników zastosowania narzędzia Kolokator ze zbiorem asocjacji słownych (Mikołajczak-Matyja, 2020), punktem wyjścia były dane z NKJP pozyskane z użyciem narzędzia Kolokator i porównane następnie ze zbiorem skojarzeń swobodnych. Wyodrębniono m.in. grupę 50 bezpośrednich rzeczownikowych kolokatów wyrazu inwalida, które nie stanowią reakcji skojarzeniowych. Stwierdzono, że wyrazy z tej grupy należą głównie do następujących kręgów tematycznych: nazwy instytucji i związków, grupy inwalidztwa, utrzymanie i praca, środowisko, działania na rzecz inwalidów, wojna i jej skutki. Stwierdzono zatem, że przeszukiwanie danych korpusowych za pomocą Kolokatora jako punktu wyjścia daje $\mathrm{w}$ efekcie wiele informacji ważnych z perspektywy społecznej, takich jak: fakt zrzeszania się inwalidów w spółdzielniach i związkach, rola dzielenia inwalidów na grupy wg kryterium tak rodzaju inwalidztwa, jak i przyczyn (inwalidzi wojenni i wojskowi stanowią częsty temat w tekstach korpusu) czy sprawy związane z ich utrzymaniem. Takie społeczne i instytucjonalne dane nie są aktywizowane w odpowiedzi na hasło inwalida w teście skojarzeniowym. Z drugiej strony potwierdzono brak w wynikach Kolokatora nazw uczuć (np. smutek, cierpienie, miłość) czy wyrazów obrazujących bezpośrednio relacje z innymi (jak akceptacja, szacunek, tolerancja), a zatem słów, bez których prozodia semantyczna wyrazu inwalida wydaje się niepełna (Mikołajczak-Matyja, 2020).

Podsumowując, można w charakterze wniosków postulować trzy główne funkcje danych otrzymywanych $z$ testu skojarzeniowego, w świetle danych korpusowych:

- wskazywanie elementów najważniejszych dla znaczenia badanego wyrazu - silnych reakcji skojarzeniowych na dany wyraz, jednocześnie często współwystępujących z tym wyrazem w tekstach, 
- ukierunkowanie wyszukiwania konkordancji,

- dostarczanie danych, których nie ma w zbiorach uzyskiwanych w wyniku przeszukiwania korpusu.

Oczywiście zasięg formułowanych wniosków jest ograniczony przez dobór wyrazu stanowiącego punkt wyjścia badań, przez liczbę i rodzaj respondentów biorących udział w teście skojarzeń, typ testu, wreszcie przez cechy NKJP i zastosowane techniki badań korpusowych. Wydaje się jednak, że przeprowadzone analizy stanowią dowód na sensowność uzupełniania badań opartych na korpusach technikami klasycznymi (a więc uzupełniania badań prowadzonych na gotowym produkcie językowym takimi, które wskazują siłę powiązań w słowniku umysłowym) i odwrotnie, zwłaszcza gdy przedmiotem badań leksykalno-semantycznych są wyrazy, pod którymi kryją się pojęcia istotne dla życia społecznego i zagrożone stereotypizacją.

\section{Zastosowane skróty}

ISJP - Inny słownik języka polskiego (Bańko, 2014).

NKJP - Narodowy Korpus Języka Polskiego, 2019.

SJPDun - Stownik wspótczesnego języka polskiego (Dunaj, 1996).

SWO - Stownik wyrazów obcych (Tokarski, 1980).

\section{Bibliografia}

Baker, P. (2006). Using corpora in discourse analysis. Continuum.

Baker, P. (2010). Sociolinguistics and corpus linguistics. Edinburgh University Press.

Bańko, M. (Red.). (2014). Inny słownik języka polskiego [ISJP]. Wydawnictwo Naukowe PWN.

Barnes, C., \& Mercer, G. (2008). Niepetnosprawność (P. Morawski, Tłum.). Sic!

Bartmiński, J., \& Panasiuk, J. (2010). Stereotypy językowe. W J. Bartmiński (Red.), Współczesny język polski (ss. 371-379). Wydawnictwo Uniwersytetu Marii Curie-Skłodowskiej.

Biernat, M., \& Dovidio, J. N. (2008). Piętno i stereotypy. W T. F. Heatherton, R. E. Kleck, M. R. Hebl, \& J. G. Hull (Red.), Społeczna psychologia piętna (J. Radzicki, M. Szuster, \& T. Szustowa, Tłum.; ss. 95-125). Wydawnictwo Naukowe PWN.

Chlebda, W. (2013). Korpusologia użytkowa dla początkujących i zaawansowanych. W W. Chlebda (Red.), Na tropach korpusów: W poszukiwaniu optymalnych zbiorów tekstów (ss. 7-15). Wydawnictwo Uniwersytetu Opolskiego. 
Nawoja Mikołajczak-Matyja Skojarzenia werbalne w Narodowym Korpusie Języka Polskiego...

Chlewiński, Z. (1992). Stereotypy: Struktura, funkcje, geneza: Analiza interdyscyplinarna. W Z. Chlewiński \& I. Kurcz (Red.), Stereotypy i uprzedzenia (ss. 7-28). Polska Akademia Nauk.

Deese, J. (1965). The structure of associations in language and thought. Johns Hopkins.

Dunaj, B. (Red.). (1996). Słownik współczesnego języka polskiego [SJPDun]. Wilga.

Górski, R. L., \& Łaziński, M. (2012). Reprezentatywność i zrównoważenie korpusu. W A. Przepiórkowski, M. Bańko, R. L. Górski, \& B. Lewandowska-Tomaszczyk (Red.), Narodowy Korpus Języka Polskiego (ss. 25-36). Wydawnictwo Naukowe PWN. http://nkjp.pl/settings /papers/NKJP_ksiazka.pdf

Greń, Z. (2001). Stereotypy jako fenomeny językowe. W M. Kofta \& A. Jasińska-Kania (Red.), Stereotypy i uprzedzenia: Uwarunkowania psychologiczne i kulturowe (ss. 67-79). Scholar.

Karwatowska, M., \& Szpyra-Kozłowska, J. (2005). Lingwistyka płci: On i ona w języku polskim. Wydawnictwo Uniwersytetu Marii Curie-Skłodowskiej.

Kiklewicz, A. (2018). Korpus internetowy jako źródło informacji lingwistycznej: Ograniczenia. Prace Językoznawcze, 20(2), 75-97. https://doi.org/10.31648/pj.4560

Kurcz, I. (1976). Psycholingwistyka. PWN.

Lewandowska-Tomaszczyk, B. (2005a). Powstanie i rozwój językoznawstwa korpusowego. W B. Lewandowska-Tomaszczyk (Red.), Podstawy językoznawstwa korpusowego (ss. 9-26). Wydawnictwo Uniwersytetu Łódzkiego.

Lewandowska-Tomaszczyk, B. (2005b). Analiza języka z zastosowaniem korpusu. W B. Lewandowska-Tomaszczyk (Red.), Podstawy językoznawstwa korpusowego (ss. 133-173). Wydawnictwo Uniwersytetu Łódzkiego.

Łobacz, P., \& Mikołajczak-Matyja, N. (2002). Skojarzenia słowne w psycholeksykologii i onomastyce psycholingwistycznej. Sorus.

Maass, A., \& Arcuri, L. (1999). Język a stereotypizacja. W C. N. Macrae, C. Stangor, \& M. Hewstone (Red.), Stereotypy i uprzedzenia (M. Majchrzak i in., Tłum.; ss. 161-188). Gdańskie Wydawnictwo Psychologiczne.

Mautner, G. (2007). Mining large corpora for social information: The case of elderly. Language in Society, 2007(36), 51-72. https://doi.org/10.1017/S0047404507070030

Mikołajczak-Matyja, N. (2012). Między psycholingwistyką, psychologią a językoznawstwem: Test skojarzeniowy jako interdyscyplinarna technika badawcza. Język, Komunikacja, Informacja, 2012(7), 101-114.

Mikołajczak-Matyja, N. (2020). Wartość korpusów językowych jako materiału do badania stereotypów osób z niepełnosprawnością: Porównanie wyników zastosowania narzędzia Kolokator ze zbiorem asocjacji słownych. Niepełnosprawność: Dyskursy Pedagogiki Specjalnej, 38, 15-30.

Mills, S. (2008). Language and sexism. Cambridge University Press.

Mollin, S. (2009). Combining corpus linguistic and psychological data on word co-occurrences: Corpus collocates versus word associations. Corpus Linguistics and Linguistic Theory, 2009(5(2)), 175-200. https://doi.org/10.1515/CLLT.2009.008

Narodowy Korpus Języka Polskiego [NKJP]. (2019, kwiecień-sierpień). http://www.nkjp.pl

Ostrowska, A. (2002). Społeczeństwo polskie wobec osób niepełnosprawnych: Przemiany postaw i dyskursu. W J. Sikorska (Red.), Społeczne problemy osób niepetnosprawnych (ss. 51-64). Wydawnictwo Instytutu Filozofii i Socjologii Polskiej Akademii Nauk. 
Peretiatkowicz-Czyż, M., \& Todys, P. (2015, luty 9). Niepełnosprawność. W Słownik RÓWNOŚĆ. INFO. https://slownik.rownosc.info/\#n

Pęzik, P. (2012). Wyszukiwarka PELCRA dla danych NKJP. W A. Przepiórkowski, M. Bańko, R. L. Górski, \& B. Lewandowska-Tomaszczyk (Red.), Narodowy Korpus Języka Polskiego (ss. 253-273). Wydawnictwo Naukowe PWN. http://nkjp.pl/settings/papers/NKJP_ksiazka.pdf PWN. (b.d.). Inwalida. W Stownik PWN. Pobrano 3 sierpnia 2019 z https://sjp.pwn.pl/szukaj /inwalida.html

Schulte im Walde, S., Melinger, A., Roth, M., \& Weber, A. (2008). An empirical characterisation of response types in German association norms. Research on Language and Computation, 2008(6(2)), 205-238. https://doi.org/10.1007/s11168-008-9048-4

Stangor, C., \& Schaller, M. (1999). Stereotypy jako reprezentacje indywidualne i zbiorowe. W C. N. Macrae, C. Stangor, \& M. Hewstone (Red.), Stereotypy i uprzedzenia (M. Majchrzak i in, Tłum.; ss. 13-36). Gdańskie Wydawnictwo Psychologiczne.

Stubbs, M. (2001). Words and phrases: Corpus studies of lexical semantics. Wiley-Blackwell.

Szałkiewicz Ł., \& Przepiórkowski, A. (2012). Anotacja morfoskładniowa. W A. Przepiórkowski, M. Bańko, R. L. Górski, \& B. Lewandowska-Tomaszczyk (Red.), Narodowy Korpus Języka Polskiego (ss. 59-96). Wydawnictwo Naukowe PWN. http://nkjp.pl/settings/papers/NKJP_ksiazka.pdf Tokarski, J. (Red.). (1980). Słownik wyrazów obcych [SWO]. Wydawnictwo Naukowe PWN.

Waliński, J. (2005). Typologia korpusów oraz warsztat informatyczny lingwistyki korpusowej. W B. Lewandowska-Tomaszczyk (Red.), Podstawy językoznawstwa korpusowego (ss. 27-41). Wydawnictwo Uniwersytetu Łódzkiego.

Więckowska, B. (2004, luty). Inwalidztwo w ujęciu medycznym i ubezpieczeniowym. Monitor Ubezpieczeniowy, 19, 32-34.

\section{Verbal Associations in the National Corpus of Polish: A Contribution to the Study of the Verbal Stereotype of inwalida 'an invalid'}

\section{Summary}

The role of corpus research in linguistics and in related fields of study has increased in recent decades. Searching for and analysis of collocations and concordances of a lexical unit, which makes it possible to determine its semantic preferences and semantic prosody, can be a tool for studying stereotypes, understood as overly generalized and simplified evaluative and affective images of a fragment of reality named by the lexical unit. The aim of this article is to verify the validity of supplementing studies based on the analysis of corpus 
resources with data obtained in free association tests. The study focuses on the lexical unit inwalida 'an invalid' as the name of a concept which may be subject to strong stereotyping. The resources of the balanced sub-corpus of the National Corpus of Polish, consisting of about 250 million words, were searched for associative responses to the word inwalida given by at least 2 people from a group of 40 Polish speakers. In the corpus, the co-occurrence of the word inwalida was checked with each of the 33 obtained associations, using a search tool to identify the contexts (concordances) containing both words - inwalida and the association - with an interval of 0 and $\leq 5$. The results of the study indicate that an association test can be a significant complement to corpus data analyses: it can provide important elements of semantic prosody which are not found in corpus analysis results, it can guide concordance search and it can indicate the elements which are the most important for the meaning of the examined word.

\section{Skojarzenia werbalne w Narodowym Korpusie Języka Polskiego: przyczynek do badań nad werbalnym stereotypem inwalidy}

\section{Streszczenie}

W ostatnich dziesięcioleciach wzrasta rola badań korpusowych w językoznawstwie i naukach pokrewnych. Wyszukiwanie i analiza kolokacji i konkordancji określonej jednostki leksykalnej, pozwalające na określenie jej preferencji semantycznej i prozodii semantycznej, mogą stanowić narzędzie badania stereotypów, rozumianych jako nadmiernie uogólnione i uproszczone oceniająco-afektywne obrazy fragmentu rzeczywistości nazywanego przez daną jednostkę leksykalną. Celem analizy przedstawionej w artykule jest weryfikacja zasadności uzupełniania badań opartych na analizie zasobów korpusowych danymi uzyskanymi w teście skojarzeń swobodnych. Przeprowadzona analiza dotyczy jednostki leksykalnej inwalida, jako nazwy pojęcia podlegającego silnej stereotypizacji. W zasobach liczącego około 250 milionów słów podkorpusu zrównoważonego Narodowego Korpusu Języka Polskiego poszukiwano reakcji skojarzeniowych na hasło inwalida podanych przez minimum 2 osoby 
z 40-osobowej grupy użytkowników języka polskiego. Sprawdzono w korpusie współwystępowanie wyrazu inwalida kolejno z każdym z 33 uzyskanych skojarzeń, używając do tego celu narzędzia szukającego kontekstów (konkordancji) zawierających oba wyrazy - inwalida i skojarzenie - w odstępie 0 oraz $\leq 5$. Wykazano, że test skojarzeniowy może w sposób istotny uzupełniać analizy korpusowe poprzez: dostarczanie ważnych elementów prozodii semantycznej, których nie ma w wynikach analiz korpusowych, ukierunkowanie wyszukiwania konkordancji oraz wskazywanie elementów najważniejszych dla znaczenia badanego wyrazu.

Keywords: corpus linguistics; National Corpus of Polish; semantic prosody; verbal associations; verbal stereotype; invalid

Słowa kluczowe: językoznawstwo korpusowe; Narodowy Korpus Języka Polskiego; prozodia semantyczna; skojarzenia werbalne; stereotyp werbalny; inwalida

Nawoja Mikołajczak-Matyja, Adam Mickiewicz University, Poznań, Poland

ORCID: http://orcid.org/0000-0003-2282-8960

Correspondence: nawomiko@amu.edu.pl

The preparation of this article was self-financed by the author.

Competing interests: The author has declared that she has no competing interests.

Publication history: Received: 2019-10-02; Accepted: 2021-02-15; Published: 2021-11-16 